\title{
Announcement about Challenges of Fruit Wine Industry in Hungary
}

\section{SUMMARY}

Everywhere in the world, the culture of grape wine goes back centuries or even millennia. In Hungary, the consumption of Hungarian grape wine plays a significant role in everyday life, while fruit wines are regarded by consumers as unknown, unusual, inaccessible premium products or as beverages for occasional consumption. In the 19th century, the drinking of fruit wine used to be preferred in Hungary. Over the years, a culture of fruit wines and production wineries has evolved throughout Europe on a fairly strong basis, and has, in an unusual way, escaped the 'attention' of Hungarian producers and consumers. The aim of this study is to explore the values and opportunities of the fruit wine sector. It is not well-known in Hungary, but there is a great deal of potential in this sector, which, as opportunities unfold, would become more widely known to the consumer soci- ety. It could become one of the potential sectors of our country besides the production of pálinka and grape wine.

Journal of Economic Literature (JEL) codes: L11, L22, Q02, Q13

Keycodes: grape wine, fruit wine, agriculture, production of wine

INTRODUCTION - THE CURRENT

SITUATION IN AGRICULTURE

Agriculture is a strategically important sector in the national economy, which is justified not only by its contribution to GDP, but also by the role it plays in safe and healthy food production, the efficient and sustainable management of natural resources, rural employment and the maintenance of the rich and diverse rural landscape (Lentner, 1998; Popp, 2017). Averages from the past few decades show that the joint share of

Dr Tímea Kozma, associate professor, Faculty of Finance and Accountancy, Budapest Business School (kozma.timea@uni-bge.hu), Dr IMre Túróczi, lecturer, Faculty of Economics, Institute of Accounting and Finances, University of Debrecen (turoczi.imre@econ.unideb.hu),SzIlveszTer Zsolnai, MSc student, Supply Chain Management, Faculty of Economics and Social Sciences, Szent István University, Dr Róbert Tóth, Director of the scientific journal Trends and Best Practices in Logistics, Head of Business Policy and Analysis (toth.robert.nemet@gmail.com). 


\section{Academic Workshop}

agriculture and the food industry in gross domestic product was 5-7 per cent, in investment 7-8 per cent and in employment 6 per cent in the last years, on average. Agriculture is one of the key sectors; however, it is also one of the most exposed to external factors (such as adverse weather conditions and natural hazards, market vulnerability).

In Hungary, the structure of agriculture is sufficiently diversified, and - similarly to other nations - it has a dual economic structure, which means that

- Capital intensive partnerships which have long-term relationships with banks and fully comply with the economy of scale principle and

- Smaller, typically sole proprietorships that often have financing issues are simultaneously present.

As in terms of management, the sector is rather fragmented, in smaller farms, both the need for and the possibility of implementing modern management instruments are at stake, and it is assumed that smaller farms do not always employ highly qualified professionals, which could significantly influence effectiveness, efficiency and financing. There are differences in the financing structure of agri-businesses from the perspective of their being present in foreign markets, carrying out export activities. Hungarian agriculture - based on CSO data - has a significant weight in exportimport (in 2019 the export grew by 8.2 per cent and the import by 8.1).

To ensure future prosperity in agriculture, it is necessary to

- improve companies' competitiveness, in both domestic and global competition,

- increase employment in the food industry,

- maintain or increase the number of jobs in rural areas;
- encourage research, development and innovation (which are closely linked to EU grants)

- and expand the fourth industrial revolution's, Industry 4.0 toolkit (which is present in digitisation, robotisation, processing massive amounts of data and process optimisation (Nagy et al., 2018).

The COVID-19 pandemic has drawn attention to the importance of countries' economic structure. It has become clear that the economic structure makes much difference. The coronavirus has also affected this sector; however, in contrast to other sectors, the pandemic has had a lesser impact on agriculture. This leads to the conclusion that agriculture, and more specifically e.g. agricultural innovation, promoting Hungarian, local products, etc. should be assigned higher priority.

\section{THE FRUIT WINE SECTOR}

Hungarian viticulture was mostly destroyed by Phylloxera, Peronospora and other disasters at the end of the 1800's, which in turn boosted fruit winemaking. Fruit wine is a fermented alcoholic beverage not made of grapes, like wine, but from other fruits. Fruit wine as a beverage which corresponds to the type of fruit, the only difference from the original fruit juice is that the sugar it contains and the added sugar are converted into alcohol. In the 19th century, fruit wine as an alcoholic beverage had a priority in Hungarian consumption; however, owing to breeding, wines made from grapes gained more ground again on the consumption ranking list. Although grape wine culture has a centuries- or even millenniaold history, it is quite inconceivable how a recently privileged product can become so forgotten that it appears as an unknown 


\section{Academic Workshop}

concept to the general public. Despite the fact that a rather strong base culture of fruit wines and production wineries has evolved throughout Europe, or in the neighbouring countries, it has, in an unusual way, escaped the 'attention' of Hungarian producers and consumers.

Fruit wine does not exist as a legal term; it belongs to the group of other fermented beverages. Not only is the name fruit wine associated with quite a few recognised products in Hungary, but its production is also rather similar to grape wine, from purchasing the raw material to delivering the finished product to the consumer - with the exception of a few materials. Regarding its origin, Hungarian consumers prefer Hungarian to foreign wines, which may result from the dominance of Hungarian wines on the shelves. In our country, the consumption of Hungarian grape wine plays a significant role in everyday life, while fruit wines are regarded by consumers as an unknown, unusual, inaccessible premium product or as a beverage for occasional ingestion.

The aim of the study is to explore the values and opportunities of the fruit wine sector. It is not well-known in Hungary, but there is a great deal of potential in this sector, which, as opportunities unfold, would become more widely known to the consumer society. It could become one of the potential sectors of our country besides the production of pálinka and grape wine.

\section{THE TIMELINESS OF THE TOPIC,} THE RESEARCH PROBLEM

Today is the renaissance of the wine and culture relationship; it is an age when customers receptive to culture are more selective in their choice, as well as value and enjoy the moderate consumption of a noble drink.
These changes in the environment require the consumer to appreciate the range of products, be willing and able to make a choice and support the sector and the operators in the sector by their purchases (Hofmeister and Totth, 2006).

Those who wish to operate a fruit winery are strongly recommended to pay a visit to as many wineries and factories as they can (either wine or fruit wine). Winemakers need to be open so that they can accept adequate and good advice easily. This helps vintners avoid obvious mistakes, moreover, it is easier to develop based on a few good tips and advice and practical experience is also important regarding the time-consuming nature of the business. Starters can obtain help and support from visiting other wineries and cellars, and talking to master winemakers in order to produce quality wines, increase their income and avoid costly mistakes (Dominic, 2007).

Unfortunately, this level of directness does not work in Hungary; that is one of the reasons why the Hungarian fruit wine sector has less than 1 per cent of the entire wine production. It is not easy to enter the fruit wine market; it requires strong competitive spirit while numerous factors influence keeping the costs low. Increased investment may improve future profit potential; however, it also increases the chances of increased failure (Mokos, 2016).

The best advice that can be given is perseverance, intelligence, morale, creativity, contact skills, attention to detail, strict differentiation at tasting and quality, and finally, luck is another key to success. Financial factors must be considered in this sector, as well. Several winemakers are not business people. They have to assess the weaknesses of their enterprise, be open and up-to-date in order to hire the appropriate person for 
eliminating shortcomings and weaknesses with a view to prospective profitability.

For those planning to open a fruit winery, the continuously increasing sector is a confidence factor, not to mention the growing trend of fruit wine consumption. However, it is of utmost importance to carry out repeated financial analyses with great care, sensibility and in detail. It is also worth learning from others' mistakes, and especially when starting up a winery, hiring an experienced winemaker. It is cost-effective, as there is a lot to learn from an experienced winemaker, which means lower error rates and it could help avoid additional costs, too. Attention must be paid to a number of areas, ranging from starting up the company, production, sales and marketing to the entire day-to-day operation of the business. Focus should be on setting up the company, production and sales, with financial details entrusted to accountants.

The results of the Corvinus University of Budapest study on willingness to taste fruit wines show that approximately 30 per cent of respondents are willing to taste sour cherry and berry products respectively. Only 19 per cent of Hungarian consumers are willing to choose perry, which enjoys great popularity in England (Perjési and Podruzsik, 2011) Figure 1 shows the well-known and common fruit wines in Hungary, which are worth integrating into supply chains, and thereby, the broadened spectrum can ensure a streamlined product flow process in the future.

\section{SUPPLY CHAIN IN THE FRUIT WINE}

\section{SECTOR}

Today, it is not companies but entire supply chains competing against each other on the market. The winners of market competition are those who can operate the supply chain
Figure 1: Willingness to taste fruit wine

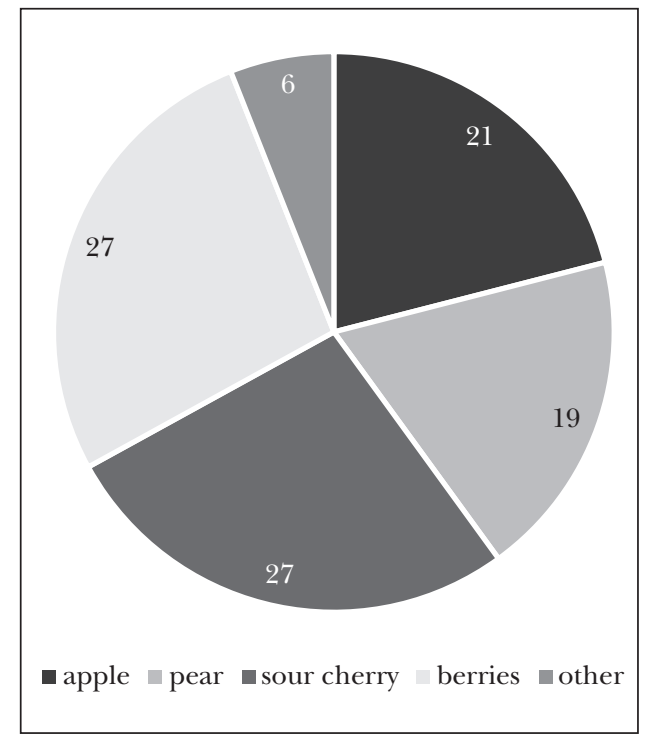

Source: Perjési and Podruzsik, 2011

the most efficiently (Kozma, 2018). To remain competitive, companies are forced to attract customers with first-class products and services, at the lowest possible price and shortest possible delivery time. The relationship between supply chains and logistics entails confusion, misuse and synonymous use (Salamonné, 2010).

A supply chain is an activity integrating key processes from the producer to the final consumer, during which process a product, service and information with value in use are created. Supply chain management is based on consumer needs and it manages all those processes that are required in delivering the value to consumers (Morgan and Monczka, 2001). Firstly, the supply chain is the group of those companies among which the product and service flow during their production. Certain individual organisations may encompass all the parts of the supply process, the production of the product and its delivery to customers - ranging from purchasing raw ma- 


\section{Academic Workshop}

terials and producing parts, wholesalers and retailers, to logistics providers. Organisation in the above definition mostly refers to an international large company, whose subsidiaries can be found worldwide and together they form a single large organisation. Looking at traditional supply chain operators, the chain begins with the supplier, whose role is to provide producers with the items needed for production. Producers manufacture the product or create the service and sell them in big batches to wholesale distributors, who in turn, supply retailers according to their respective catchment area. Retailers sell the product to the final user, the consumer. The relationship among the operators in a chain is characterised by logistics services and information relationships.

A short supply chain ( $\mathrm{SSC}$ ) is comprised of a small number of economic operators, who are committed to co-operation, local economic development and close geographical and social relations between producers, processors and consumers. At present, traditional SSCs are relatively easily accessible to consumers and producers alike; however, without developing cooperation, the sustainable operation of both modern SSC types and traditional forms is highly uncertain. In addition, farmers, especially smaller enterprises that are not competitive independently, find it hard to react with development to new challenges. The need to strengthen the social recognition of short supply chains means that SSC producer and consumer visibility and recognition need to be strengthened alike (Szabó, 2014).

Local food and the related short food supply chains attract more and more attention from consumers, consumer representation and rural development civil society organisations, producer organisations and decision-makers at all levels. There are sever- al problems concerning the sustainability of the traditional food industry (Duleba, 2006) (environmental impact, economic and ethical problems due to the dominance of multinational retail chains, food safety considerations, etc.); short supply chains could provide a solution to these problems for consumers and producers as well. A short supply chain means that production, processing, transportation and consumption occur in close proximity (Duleba, 2008), that is, these processes take place in a predetermined area (according to the relevant Hungarian regulation, within $40 \mathrm{~km}$ ), and the number of the intermediaries between the producer and the consumer is low (Benedek et al., 2014; for SSC forms: Szabó, 2013).

Direct: the producer sells to the final consumer in person or in cooperation:

- "Open farm": farmyard, village guest table, U-pick, community supported agriculture

- "Points of sale": market, producer market, festival, fair, farm shop

- "Home delivery": box system, online sales, moving shop.

Short: the producer sells to an intermediary in person or in cooperation:

- Catering,

- Mass catering,

- Food retail.

\section{THE FOOD MILE (FOOD KILOMETRE)}

\section{CONCEPT}

The European Agricultural Fund for Rural Development (EAFRD) regulation defines short supply chain as "a supply chain involving a limited number of economic operators, committed to co-operation, local economic development, and close geographical and social relations between producers and consumers". Small geographical distance is 


\section{Academic Workshop}

Figure 2: Sales channels of the fruit winemaking supply chain

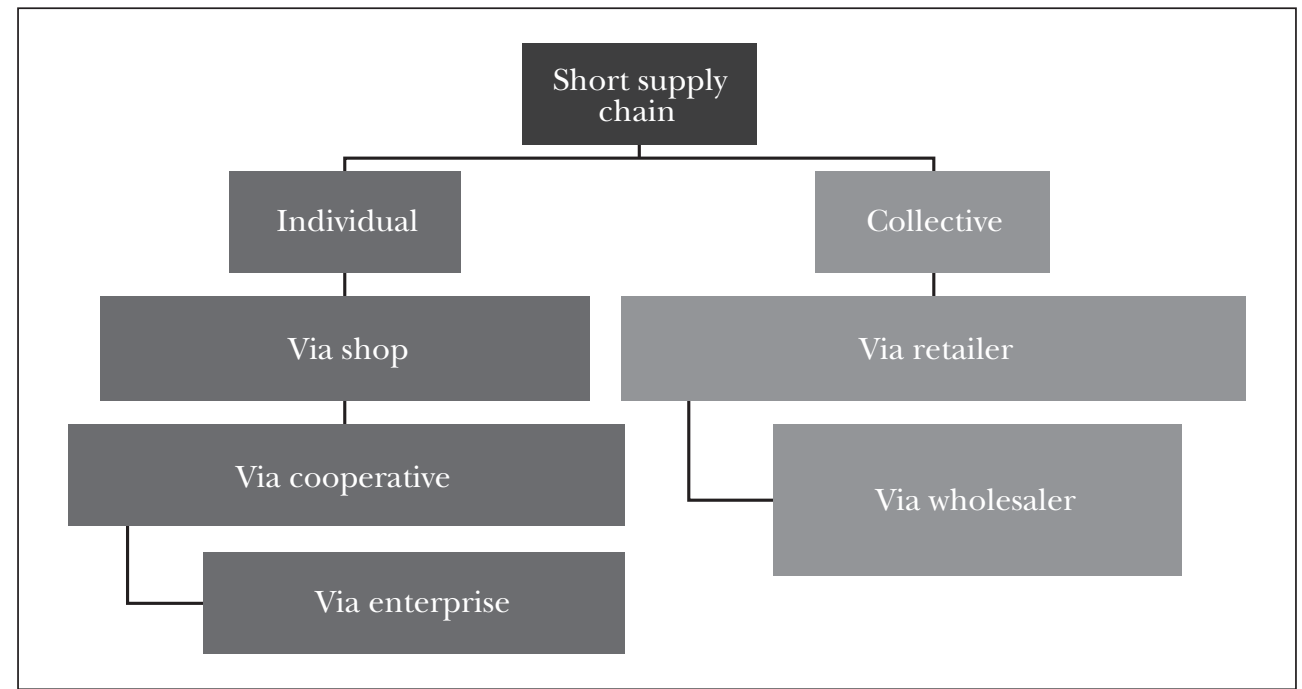

Source: Authors' elaboration

a key to SSC; however, based on consumer surveys, "local" has multiple understandings. While in Hungary regulations determine local products within a $40 \mathrm{~km}$ distance, in the United States of America, it means a distance of 400 miles $(644 \mathrm{~km})$. Obviously, the applied measure influences what is socially acceptable in terms of the distance food travels, that is, how big the energy demand and the emission of greenhouse gases of transport are (Benedek et al., 2014).

Unlike the path of a product in traditional supply chain going through various opera- tors, in certain companies multiple supply chain processes are concentrated within the activity frameworks of one business. In case of wineries, it is often not possible to differentiate purchasers/suppliers, producers and intermediaries, they are involved in a single organisation.

Based on Figure 3, it is clearly visible which stages of the short supply chain fruit wine as a final product (in the case of winery with own vineyard) goes through, from planting the vineyard to delivery to the final consumer.

Figure 3: The process of fruit wine traveling along the supply chain

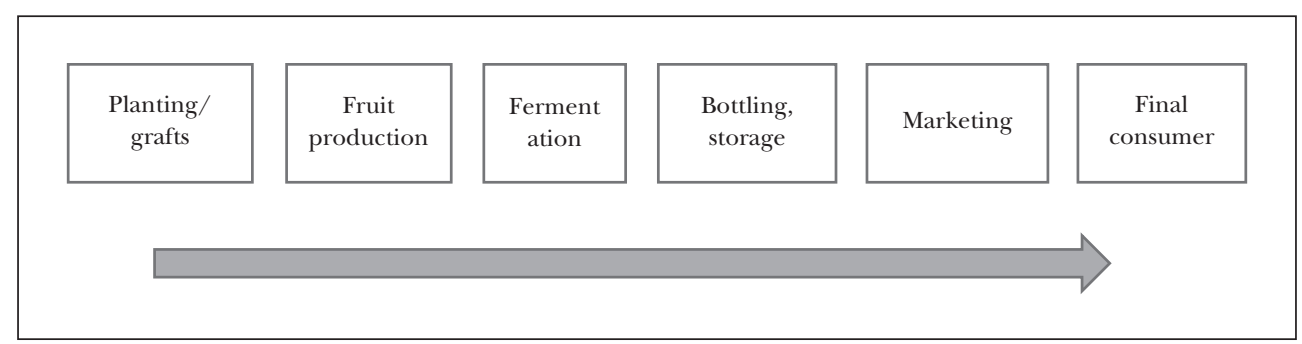

Source: Authors' elaboration 


\section{Academic Workshop}

\section{Fruit WINE POSITIONING}

In Hungary, the annual wine sale is about 2.5 million $\mathrm{hl}$, with an annual per capita wine consumption of approximately 30-32 litres, while according to surveys, half of the Hungarian population does not consume wine at all. There are historical reasons for the significant consumption in Hungary. In 2007, 27 per cent of the wine came directly from winemakers or Hungarian production (Konkoly, 2012).

Traditional Hungarian winemaking is maintained by $5-8$ per cent of the wineries, of which 10-12 leading producers predominate in Hungarian chain stores. Naturally, smaller wineries are also present in supermarkets, albeit with smaller selections (Domán, 2009). Presently, there are hardly five registered businesses producing a marketable amount of fruit wine in Hungary; however, product awareness among the public is due to Hungarian production. Fruit wine barely amounts to 5 per cent of the total wine consumption, within this, own consumption has a remarkably high rate at about 75 per cent. Although Hungarian wine-drinkers tend to be open to novelty, they would rather choose established practices, customary tastes and convenience in most cases.

One of the consequences of oversupply characterising most consumer markets is that today's consumers are getting more sophisticated, although it is significantly hindered by subjective perception partly determined by limited information uptake and partly by intensive marketing activities from companies. Consumer needs, however, are greatly formed by companies as well; spontaneous real consumer demand is less and less prevalent owing to the rapid technical and technological development. The desire for fully catering to demands, or, from the business perspective, for profit maximisation, encourages and forces companies to get a full understanding of these consumer expectations and adjust their production capacities accordingly (Szúcs, 2008).

In the food industry, and more specifically, in the beverage trade, supply hardly ever meets demand, since consumer behaviour and their demand for the products cannot be determined. Therefore, to avoid potential market shortages, there is often oversupply on the market, which is more intensive in the case of fruit wines, as the majority of consumers are not prepared for noticing the products well enough to ensure their mass sales. In order to achieve a better utilisation of demand, the application of promotional marketing instruments that are closely linked to consumer needs is required.

Advertising, and in general marketing communication provides ample examples for referring to value. From the perspective of wine, it is sad that several values that we traditionally associate with wine, are linked to one of the most significant wine substitutes, beer, as a value related to the beer brand, e.g.: friendship, company, entertainment, cheerfulness, intimacy (Deák, 2013).

When using adequate marketing and other instruments, pricing also shows a different direction from the point of view of the product. The applied pricing strategies are different for New World and European wine. European producers focus on lowprice Popular premium, and high-quality and costly Ultra-premium categories. In contrast, New World wine producers prioritise the Super premium segment by expanding the selection of high-quality and high-price wines. They regard Central and Eastern European wines low-price, in the lack of 


\section{Academic Workshop}

image, which, as added value, could bring extra profit to winemakers (Sidlovits, 2008). Fruit wines that now appear as a rarity on the market are in the premium pricing category, while their production and treatment are greatly similar to that of grape wines. Thus, to ensure greater awareness, pricing should be lower in the future, or it has to be established in the sector for once that fruit wines are meant to meet the demands of a higher, more sophisticated consumer group.

In the countries of the European Union there are different rules and regulations regarding fruit wine production and placing on the market. They prescribe the amount of distilled alcohol that can be added to achieve the alcohol strength, the concentrated fruit content of the base, and, obviously, compliance with quality criteria regarding the final product. All European rules allow the addition of water. Sugar and honey addition are a constant debate; however, there are hardly any products on the shelves of Hungarian supermarkets that do not contain a considerable amount of added sweetener - beside the sugar needed for fermentation. The European Cider and Fruit Fine Association provided guidelines regarding standardised fruit wine production. In view of the above, entering the export market is a possibility. The domestic oversupply could primarily be sold in countries with a greater consumption culture, such as Great Britain, France and Spain.

\section{FRUIT WINE-MAKING MACRO}

ENVIRONMENT (PEST ANALYSIS)

We examined the situation of fruit winemakers using direct sales and indirect product distribution using a PEST (Political, Economic, Socio-cultural and Technological) analysis, along four dimensions.

\section{Economic policy factors}

Premarketing qualification obligation is specified by law. According to Article 24/A of Act XVIII of 2004 on Viticulture and the Wine Industry (hereinafter: Wine Act), wine industry products - with the exception of fresh wine-grape, concentrated wine-grape, botrytised wine-grape, crushed fresh wine-grape and grape must - can only be marketed for public consumption, or exported from Hungary for further processing, if the Hungarian wine authorities have carried out analytical and organoleptic tests and have established the quality, or an authorised body of a party to the Agreement on the European Economic Area, or other legally determined European organisation has established and approved their quality as compliant with the regulations they are subject to.

Fruit wine is not listed as an excise good in excise legislation; however, other fermented beverages (e.g. cider, perry) fall under tariff heading 2206, and fall into the excise good category as other still fermented beverages, based on Article 3 (3) 10 b) of Act LXIII of 2016 on Excise Taxes (Horváth, 2017).

At present, beside value added tax, fruit winemakers and vendors are only subject to paying one type of tax (which can be viewed as excise tax), which involves the payment of a ten-thousand HUF tax per hectolitre according to regulations.

\section{Economic factors}

At the end of the 1800 s, viticulture was mostly destroyed by Phylloxera, Peronospora and other disasters all over Europe; in Hungary until 1897 out of 666,820 (kataszteri) hold (equivalent to app. 383,700 ha) 


\section{Academic Workshop}

vineyard 391,217 (app. 225,000 ha) was destroyed. Afterwards, wine production significantly decreased and fruit winemaking started to boom and become slightly more prominent. During this time, the attempt to refill vineyards with selected vine stocks as substitutes, as we all know, was a major success. Nearly one hundred years - while fruit wine substituted wine on the market - were not enough to improve its public awareness and acceptance.

The accession to the European Union brought increased union regulations and administrative burden to winemakers. In addition, the effects of the 2008 economic crisis are still felt in the sector, after which willingness to purchase wine became significantly lower and it is still stagnant.

\section{Social/cultural factors}

It is an important factor that fruit wine does not have a historical past and the concept, the taste and the product itself has a low level of public recognition. In general, 80 per cent of the Hungarian population have already tasted fruit wine, some even prepared it at home as a hobby or made it for domestic consumption in the family.

The age pyramid of Hungary shows a constant aging trend, which is not necessarily a positive prognosis with regard to fruit wines, as older generations are less likely to accept novel innovative products and their consumption is based on habits. In contrast, younger consumers do not represent enough consumer power to influence customer standard means, despite having entirely different expectations than their ancestors regarding alcoholic beverages. The young generation is open to novelty, and can learn about unknown products that piqued their interest easily due to in- creased information flow. Nowadays, a high priority is given to the consumption of exotic products, and fruit wine as a product falls into this category. Eating and drinking habits have also changed: grape-wine, which used to be an everyday product, has become an indulgent product, thereby table wines have disappeared from regular meals and they have been replaced by the less frequent, occasional consumption of quality wines. Fruit wine is characterised by lower quantities of consumption; a particular section of society drinks it as a dessert wine.

\section{Technological factors}

After the European accession a wide range of opportunities opened for active factories and new wineries. Especially in the 20072013 programming period, when several billion HUF agricultural and rural development grants (Popp et al., 2017; Popp et al., 2018a; Popp et al., 2018b) were made available to provide producers alternatives for using new technologies and techniques, and investing in machinery and equipment. Sadly, however, the technological upgrades and investment could not ensure an advantage in the fruit wine sector, since, as detailed earlier, according to legal definition, fruit wine does not belong to the wine family and thus no grants were available for process development or production.

There is only one instrument to improve fruit wine recognition in the lack of grants and innovation: a method, which integrates wine products made from fruit as diversification among the products of well-known wineries and cellars. An example for such a process was applied by the Mokos Winery. Starting as wine producers, the company grew into a recognised winery in the Villány 


\section{Academic Workshop}

wine region. Then, carrying out sectoral expansion in a year of good harvest, they began producing and experimenting with fruit wines. The winery has dealt with fruit winemaking and sales since 2007.

\section{Primary QUESTIONNAIRE CONSUMER SURVEY}

In order to explore the situation of the fruit wine sector compared to its competition, grape-wineries, we conducted a questionnaire survey among consumers to measure consumer readiness for innovation. Due to their characteristics, fruit wines belong to high-price category products. Production costs and intrinsic value draw the lowest line in pricing at 2,000 $\mathrm{HUF} /$ bottle (0.5 litre) at present. The taste itself is not compatible with every meal or even everyday consumption. Considering the price and the quality, it is mostly targeted at the better-off. Figure 4. shows well how much the respondents are willing to spend on certain fruit wine products. Based on the above, respondents remained in the common 1000-2000 HUF price category, since they used grape-wines for reference due to unfamiliarity with the production and the value of the product.

80 per cent of the respondents said that they would love to try fruit wine, or consume it alongside wine. In comparison with fruit spirits, they regard fruit wines exotic, premium products. Therefore, building on consumers open to innovation, winemakers marketing fruit wine as a diversified product could achieve stable sales and profit.

Fruit wine as a product only appeared in Hungary in the mid-2000s, and is therefore considered an unknown product on the market. Winemakers that has made a name for themselves with grape-wine have grapewine machinery and equipment acquired on EU grants, and a solid customer base. Based on their references, the introduction of a new product, besides improving local value added, could help attract more consumers and raise the public's brand awareness.

Figure 4: Willingness to spend based on price categories

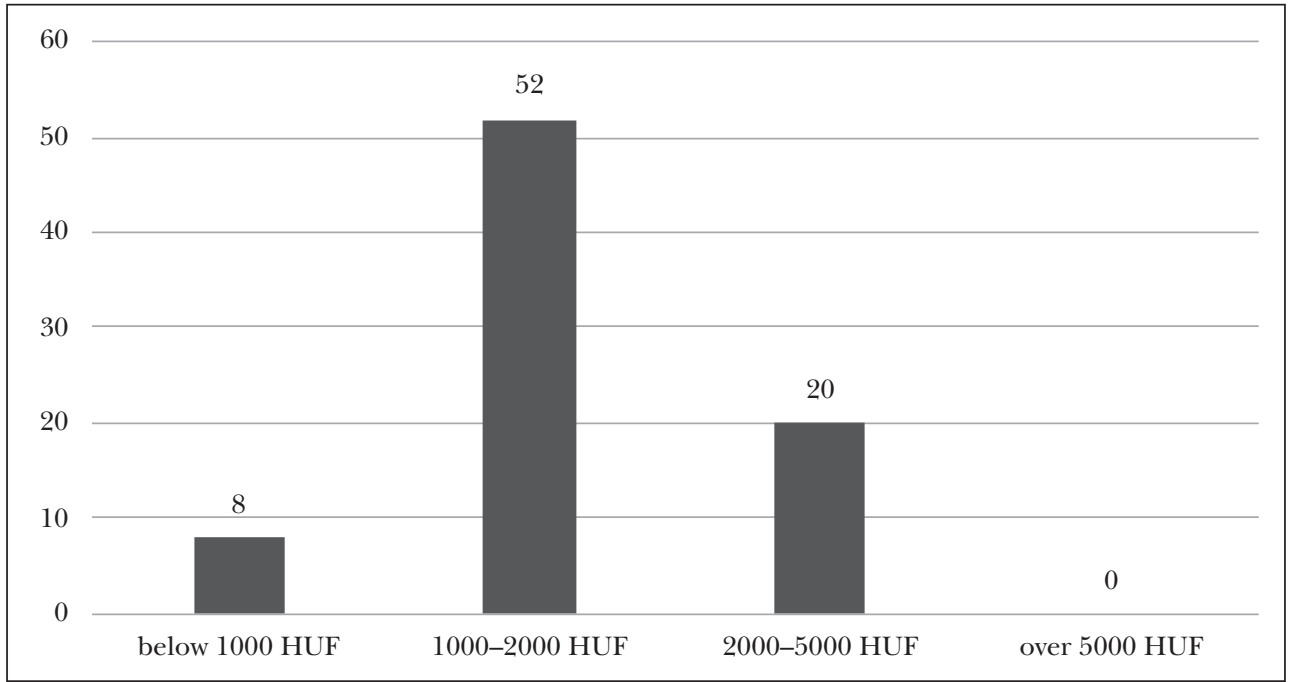

Source: By the authors (2019) 


\section{Academic Workshop}

The new generation of fruit wineries and cellars that did not receive grants and have lower rates of working capital, could use the handcrafted concept as a resource to attract customers. Today production is characterised by automation and mass production; consequently, customers highly value products manufactured with hand and without the use of external power.

Hungary's first handcrafted fruit wine manufactory, the Sápi Tímea Handcrafted Fruit Wine Manufactory applies the appropriate, detailed method which gives them competitive advantage. They only use natural ingredients, process first-class fruit immediately and fermentation happens at a regulated temperature. Fermentation is done using reduction, that is, in containers in an oxygen-free environment. To ensure the sweetness of the wines, fermentation is stopped by cold crashing. The yeast dies but the internal content value remains intact. Another benefit is that they use 100 per cent fruit during processing, the products do not contain any flavour or fragrance enhancers. This earned them the Hungaricum premium rating as their wine products no not contain artificial ingredients and have high quality. Bottling and corking are done without the use of machinery. They do not use bottling lines, they manufacture wine manually, just like in the old days. Focusing on preserving traditions, they are planning to continue manufacturing this way. Although it requires more work, a quality product deserves the attention. The basic principle is quality, so mass production and multinational marketing are non-objectives. The company has won several prizes in prestigious Hungarian and foreign competitions. What they are proudest of is the Hungaricum premium qualification, which is a trade mark at the same time. In March 2019 they introduced their novel wine named Blue Blood, made from natural ingredients. When the Kossuth Radio learnt about the news, they made an interview, which was a huge success for the company.

It is a debated issue whether fruit wine can ever stand in competition with grapewines. Grape-wines have a great long history with a well-beaten path and high recognition all over Europe, and in Hungary, as well. Despite this, fruit wine recognition is particularly low in our country.

The study clearly showed consumer readiness. Interest has a decisive role, however, as the figure also shows, that the frequency of consumer willingness is rather low: consumers would only open a bottle of fruit wine on holidays, for important events. The figure would be just the opposite for grape-wines in terms of occasional and more frequent consumption (Figure 5).

Based on the above, although in consumers' knowledge fruit wines enjoy premium status, they would not go beyond a one-time or occasional tasting and consumption. In contrast to grape-wines, they could only gain priority again, if people's tastes in wines underwent a radical change or new devastating vine diseases appeared in the future.

Figure 6 shows that, based on available 2017 data, the size of orchard territories exceeds the overall size of vineyards by 20 per cent. Considering the flavours and the various types of fresh fruits, not many people give a thought to the fact that similarly to grape-wines, it is possible to ferment fruit to make alcohol and wine. Regarding the territorial distribution of plants, we can say that on the considerably larger orchard plantations, the volume of wine production could reach comparable, if not better, results as the amount of wine produced on 


\section{Academic Workshop}

Figure 5: Fruit wine consumption frequency

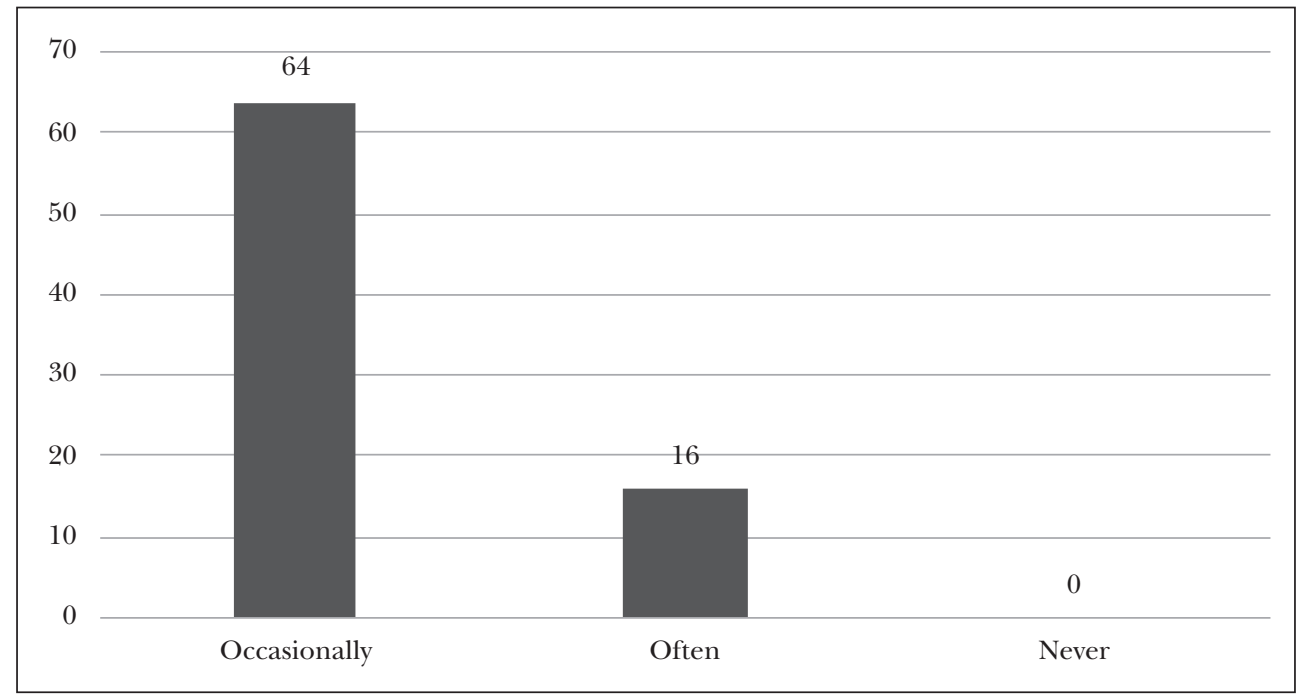

Source: By the authors (2019)

the smaller vineyard areas (which also grow fresh fruit produce).

In Hungary fruit winemaking barely goes back to a decade; therefore, the concept itself is relatively unknown (does not even exist in legal terms), the product is not integrated into public awareness, and, consequently, it is often neglected. The Hungarian people are becoming more open to innovation, yet, the majority of consumers still assume that grape is used for wine-making, while fruit is used for making pálinka.

Figure 6: Hungarian orchards and vineyards, in 1,000 ha

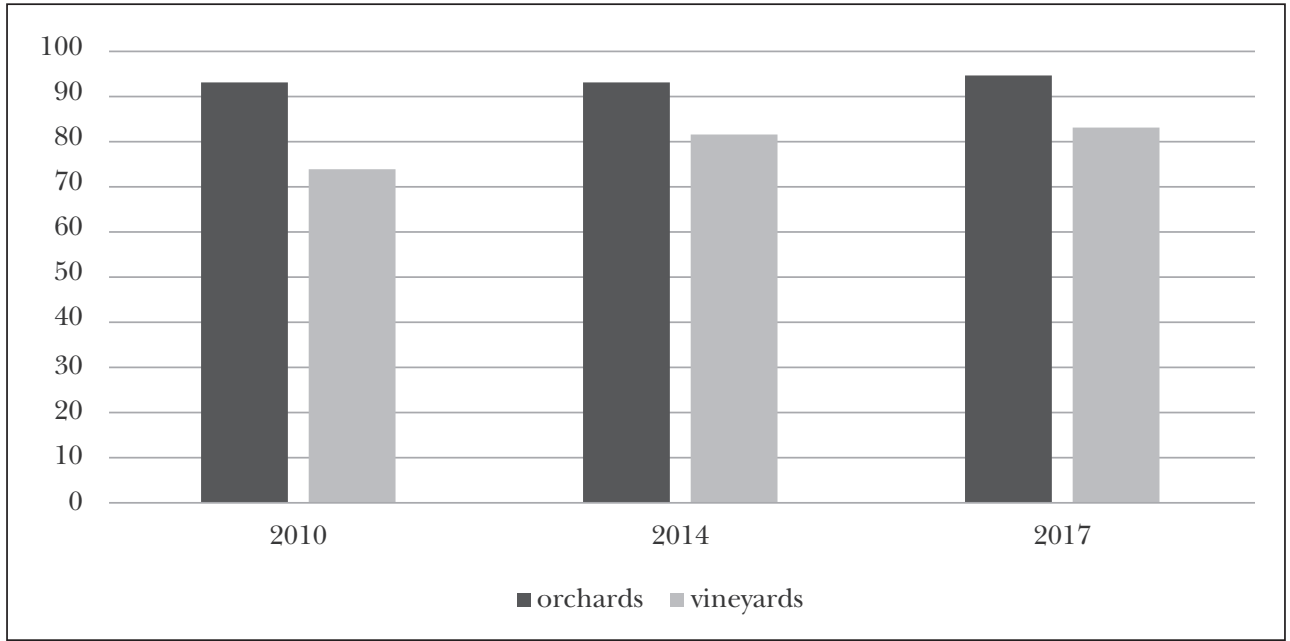

Source: By the authors based on KSH datas 
Figure 7: Type of wine customer choice

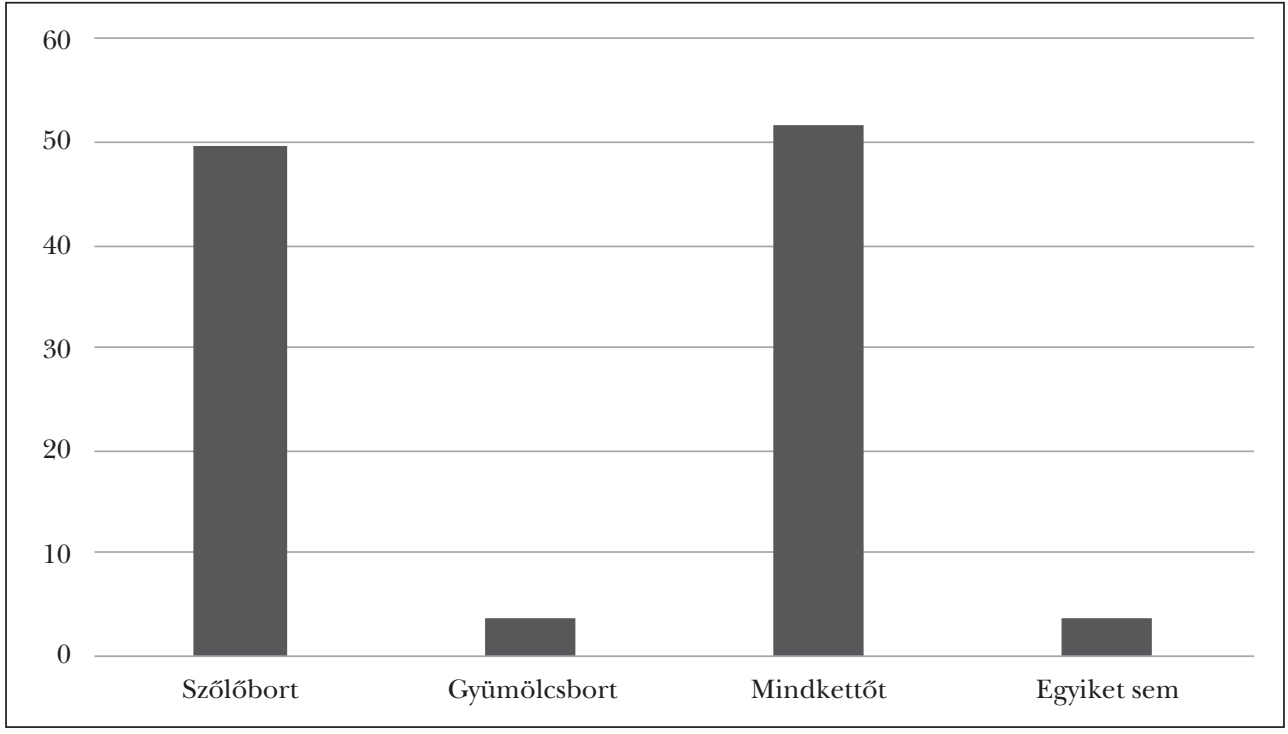

Source: By the authors (2019)

Alongside grape-wines, fruit wines are becoming more common on the shelves of supermarkets. Consumers have the opportunity to choose from the two types. Customers are willing to buy innovative products, the majority of respondents would purchase and try both types of products to ensure that in case the fruit wine does not live up to their expectations, they could still resort to the grape-wine of usual quality. As the figure shows, given one choice only, the popularity of grape-wine is four times that of fruit wine (Figure 7).

\section{Conclusion}

The fruit wine sector is a production sector in the initial phase of development, whose supply chain is relatively vague and the process is uncertain. The product has two routes: it can go through the areas and actors of the chain in the traditional or the SSC way. Hungarian grape-wine (and spirit) production dominates the market, while wines made from fruit barely reach a 1 per cent wine market share. Thanks to the geographical features of the Carpathian Basin, numerous types of fruit thrive in Hungary, and this characteristic and the potential is too great to be missed. Given the size of our country and its cultural heritage, the fruit wine sector is less prevalent, yet both its values and opportunities are among the best in Europe.

The questionnaire consumer survey has shown that although consumers are willing to accept innovation and they do not reject fruit wine as a new product, potential consumers are still not ready for exclusivity or greater consumption. In view of its fruit quality and values, Hungary has the ability to produce for the world (export) market; however, the Hungarian fruit wine market is dwarfed by its foreign counterparts. The primary objective is to achieve expansion on the local market. 


\section{Academic Workshop}

Alongside grape-wine production, the volume of fruit winemaking should be given a boost, which would be ideal and beneficial for the entire wine sector, Hungarian and foreign alike. Hungarian grapewine marketing on the world market is relatively low standard - mostly because of the limitations from the size of the country -, but they have gained popularity within the borders and in the neighbouring countries, as well. However, the same does not apply to fruit wines; in their case, improved marketing areas could help product awareness, recognition, and make them more tangible and accessible for consumers.

In contrast to fruit spirits, fruit wines are viewed as exotic, premium products. Therefore, building on consumers being open to innovation, winemakers marketing fruit wine as a diversified product could achieve stable sales and profit.

\section{REFERENCES}

Benedek, Zs.; Fertô, I.; Baráth, L. and Tóth, J. (2014): Termelôi heterogenitás a rövid ellátási láncokban: a piacokon értékesitó gazdák jellemzô különbségei [Producer heterogeneity in short supply chains: farmers selling in markets]. https:// core.ac.uk/download/pdf/42927875.pdf.

Domán, Sz. (2009): A borfogyasztói és -vásárlói magatartás fontosabb összefüggéseinek vizsgálata [Analyses of the most important correlations of wine consumer and buyer behavior]. PhD dissertation, Szent István University, Gödöllô.

Duleba, Sz. (2006). Logistic Trends of the Supply Chains in the Food Industry. Economics and $\mathrm{Or}$ ganisation of Enterprise, Vol. 57, No. 10, 98-106.

Duleba, Sz. (2008): Hungarian Characteristics of Logistic Trends in the FMCG Sector. Economics and Organisation of Enterprise, Vol. 59, No. 5, $43-50$.

Hofmeister Tóth, Á. and Totth, G. (2006): Fogyasztói szokások alakulása a magyar borfogyasztásban. Az értékek szerepe a borvásárlásban [Consumer habits in Hungarian wine consumption. The role of values in wine buying]. In: "Stratégiák
2007 és 2013 között" [Strategies between 2007 and 2013]. Conference paper, Budapest Business School, 189-202.

HCSO (2015): Magyar Statisztikai Évkönyv, 2014 [Statistical yearbook of Hungary]. Hungarian Central Statistical Office, www.ksh.hu/docs/ hun/xftp/idoszaki/evkonyv/evkonyv_2014.pdf.

Konkoly, M. (2012): Marketingeszközök a tokaji borok pozicionálásában [Marketing tools in positioning Tokay wines]. PhD dissertation, Szent István University, Gödöllő.

Kozma, T. (2018): Szereplôk, folyamatok, kapcsolatok az ellátási lánc mentén [Actors, processes, relationships along the supply chain]. In: Logisztikai évkönyy 2018 [Logistics annals]. Magyar Logisztikai Egyesület, 23-35.

Lentner, Cs. (1998): Dilemmas of Hungary's Agricultural Future Contrasted with its Historical Background and Developed Market Economy Models. In: Gidai, E. (ed.): On the Eve of the 21st Century. Challenges and Responses. Akadémiai Kiadó, Budapest, 175-185.

Lentner, Cs. (2004): A magyar agrárfinanszírozás jellemzôi az EU-csatlakozás küszöbén [Characteristics of Hungarian agricultural financing on the threshold of EU accession]. Gazdálkodás, Vol. 48, No. 1, 69-78.

Mokos, B. (2016): Mokos Pincészet leíró elemzése [Descriptive analysis of Mokos Winery].

Morgan, J. and Monczka, R. (2001): Strategic Supply Chain Management. Purchasing Magazine.

Nagy, J.; Oláh, J.; Erdei, E.; Máté, D. and Popp, J. (2018): The Role and Impact of Industry 4.0 and the Internet of Things on the Business Strategy of the Value Chain - The Case of Hungary. Sustainability, Vol. 10, No. 10, https://doi. org/10.3390/su10103491.

Perjési, J. and Podruzsik, Sz. (2011): A gyümölcsborok kedveltsége a magyar borfogyasztásban [The popularity of fruit wines in Hungarian wine consumption]. Élelmiszer, Táplálkozás és Marketing, Vol. 8, No. 1-2, 55-60.

Popp, J.; Fazekas, P.; Hollósi, D. and Oláh, J. (2017): A versenyképes mezôgazdaság, a földár és a föld jövedelemtermelő képességének összefüggései [Relationships between competitive agriculture, land prices and land income-generating capacity]. Gazdálkodás, Vol. 61, No. 6, 491-504.

Popp, J.; Erdei, E. and Oláh, J. (2018a): A precíziós gazdálkodás kilátásai Magyarországon [Prospects for precision farming in Hungary]. Múszaki 


\section{Academic Workshop}

és Menedzsment Tudományi Közlemények, Vol. 3, No. 1, 133-147, https://doi.org/10.21791/ IJEMS.2018.1.15.

Popp, J.; Petô, K. and Oláh, J. (2018b): Short Food Supply Chains in Europe: Differences between the EU15 and $E U-13$. Conference paper, IAAE, https:// ageconsearch.umn.edu/record/277136/.

Rivard, D. (2009): The Ultimate Fruit Winemaker's Guide. The Complete Reference Manual For All Fruit Winemakers. CreateSpace Publishing.

Salamonné Huszty, A. (2010): Kis- és középvállalkozások menedzsmentje [Management of small and medium enterprises]. University coursebook, Szent István University, Gödölló.

Sidlovits, D. (2008): Vertikális koordináció a szôlố- és borágazatban [Vertical coordination in the wine sector]. $\mathrm{PhD}$ dissertation, Corvinus University of Budapest.

Szabó, D. (2013): Kistermelôk válaszúton: a rövid ellátási láncban rejlô lehetôségek és veszélyek Magyarországon [Small producers at a crossroads: opportunities and threats in the short supply chain in Hungary]. Hungarian Regional Science Association 11st Annual Meeting, Kaposvár.
Szabó, D. (2014): A rövid ellátási láncban rejlô lehetôségek és veszélyek Magyarországon [Opportunities and threats in the short supply chain in Hungary]. Acta Carolus Robertus, Vol. 4, No. 2, 109-118.

Szabó, D. (2017): A rövid ellátási lánc Magyarországon. Research Institute of Agricultural Economics, Budapest, http://www.fao.org/fileadmin/user_upload/reu/europe/documents/ events2017/stbihhu/8.pdf.

Szúcs, K. (2008): Fogyasztói piacok szegmentációja a trendaffinitás dimenziójában [Segmentation of consumer markets in the dimension of trend affinity]. PhD dissertation, University of Pécs.

United Brands (2013): Gyümölcsbor-történet [The history of fruit wines]. http://hirlevel.unitedbrands.hu/201402/35.

Vécsey Bánk (2013): A bortermelés története a kezdetektôl napjainkig [The history of winemaking from the beginnings to the present]. Borászportál.hu, www.boraszportal.hu/hirszuret/ a-bortermeles-tortenete-a-kezdetektol-napjainkig-4420. 